\title{
IMPLEMENTASI TAKWIL DALAM TAFSIR AL-KASYSYAF OLEH AL-ZAMAKHSYARIY
}

\author{
Bilfahmi Putra \\ Dosen Fakultas Ushuludddin dan Studi Agama \\ UIN Imam Bonjol Padang \\ bilfahmip@gmail.com
}

\begin{abstract}
This problem is motivated by the very striking difference between alZamakhsyariy with other mufassir in interpreting (mentakwil) verses of the Qur'an. The subject matter is: how can the implementation of takwil that conducted by al-Zamakhsyariy in the Tafsir al-Kasysyaf, limited by one restrictions; how the results of the form takwil. This study aims: to found the form of takwil that clear. This research is library research, primary data source is al-Kasysyaf, and secondary data source is books, journals scientific and documents related with these discussion, the methods used in this study is qualitative method and content analysis. While the results of penakwilan process conducted al-Zamakhsyariy is; Al-Zamakhsyariy mentawkilkan the verses mutasyabih, and the verses or pronunciations that are contrary to the understanding of the Mu'tazilah, mentawkilkan the verses not mutasyabih.
\end{abstract}

Keywords: Implementasi Takwil, Tafsir al-Kasysyaf, al-Zamakhsyariy

\section{PENDAHULUAN}

Al-Qur'an telah membuktikan keutamaannya sebagai hudan li al-nas (petunjuk bagi manusia), bayyinat min al-huda (penjelasan lebih lanjut dari petunjuk) dan al-furqan (pembeda antara yang haq dengan yang bathil terdapat pada (Q.S. al-Baqarah/ 2: $185)^{1}:$ :

1 Petunjuk bagi manusia maksudnya adalah bahwa al-Qur'an adalah kitab yang Maha Agung, sehingga secara berdiri sendiri ia merupakan petunjuk. Banyak nilai-nilai universal dan pokok yang dikandungnya, tetapi nilai-nilai itu dilengkapi lagi dengan penjelasan-penjelasan lebih lanjut mengenai petunjuk itu, yakni keterangan dan rinciannya. Lihat Muhammad Quraish Shihab, Tafsir al-

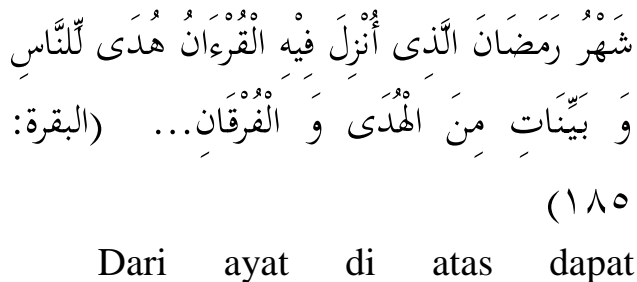

disimpulkan bahwasanya, al-Qur'an memiliki kandungan makna yang bisa memberikan petunjuk kepada umat manusia, baik petunjuk dalam mencapai keselamatan dan kebahagiaan dalam kehidupan di dunia maupun petunjuk dalam mencapai keselamatan dan kebahagiaan di

Mishbah, Pesan, Kesan dan Keserasian alQur'an, (Jakarta: Lentera Hati, 2000), juz I, Cet. ke-1, h. 378 
akhirat. Untuk itu, dibutuhkan penafsiran al-Qur`an yang komprehensif sehingga ia berfungsi maksimal sebagai petunjuk bagi manusia.

Dalam memahami isi kandungan al-Qur`an, banyak hal yang mempengaruhi penafsirannya. Salah satu yang sangat mempengaruhi perkembangan interpretasi dan penafsiran al-Qur'an adalah takwil. Kata takwil adalah derivasi/ isytiqaq dari kata آل - أول - yang berarti الرجوع (kembali). Kemudian dari kata دبر yang berarti تأويل yancul kata وقدر (mengatur dan menentukan ukuran/batasan sesuatu). Dengan kata نقل ظاهر اللفظ عن وضعه الاصلى إلى ما يحتاج

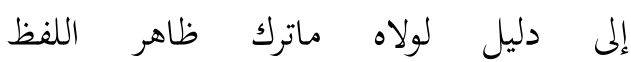
(memindahkan makna zahir lafal dari makna semula pada makna yang dibutuhkan oleh dalil, namun apabila pemindahan lafal tidak ada, makna zahir lafal tetap saja tidak ditinggalkan). ${ }^{2}$

Ulama salaf berbeda pendapat dalam mendefinisikan takwil; Pertama, takwil adalah menafsirkan sebuah ungkapan dan menjelaskannya baik sesuai ataupun berlawanan dengan makna zahirnya. Dalam hal ini takwil dan tafsir cukup mirip. Pendapat ini didasarkan kepada apa yang diungkapkan oleh Mujahid ketika

\footnotetext{
${ }^{2}$ Muhammad ibn Mukrim ibn Manzur al-Afriqiy al-Mishriy, selanjutnya disingkat dengan ibn Manzur, Lisan al-Arab, (Beirut: Dar Shadir, t.th), juz XI, h. 32

72
}

menafsirkan surat Ali Imran/ 3: 7 tentang takwil ayat-ayat mutasyabihat; Kedua, takwil adalah jiwa atau inti dari sebuah ungkapan. Apabila sebuah ungkapan itu perintah, maka takwilnya adalah inti dari perbuatan yang diminta dan apabila ungkapan itu berupa informasi, maka takwilnya adalah inti atau jiwa dari informasi tersebut. Di sini dapat dipahami bahwa takwil dalam pengertian kedua ini adalah inti atau jiwa yang terdapat di luar ungkapan.

Selanjutnya ulama kontemporer صرف mendefinisikan takwil dengan اللفظ من المعنى الراجح إلى المعنى المرجوح لدليل يقترن به (mengalihkan lafal dari makna yang kuat kepada makna yang lemah dikarenakan adanya dalil atau indikator yang mengiringi atau menghendakinya). Dari pengertian ini juga terlihat bahwa takwil tidaklah sama dengan tafsir, di mana takwil lebih mengarah pada pemalingan lafal, sedangkan tafsir lebih mengarah pada penjelasan atau interpretasi. $^{3}$

Seiring dengan perkembangan zaman dan semakin tingginya perhatian umat Islam khususnya pemerhati alQur'an terhadap kajian tafsir dan takwil, juga menyebabkan terjadinya perkembangan terhadap takwil. Hal ini dapat terlihat dalam penafsiran (Q.S. Thaha/ 20: 5)

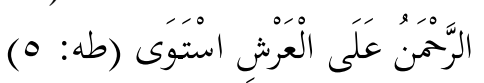

Ulama-ulama klasik seperti ala'labi dalam kitab al-Kasysyaf wa alBayan mengutip pendapat Malik ibn

3 Muhammad Husain al-Zahabiy, alTafsir wa al-Mufassirun, (Kairo: Maktabah Wahbah, 2000), Cet. ke-7, h. 15 - 16 
Anas yang ia riwayatkan dari Muhammad ibn Syuja' ketika menafsirkan ayat ini:

عن محمد بن شجاع البلخي قال : سئل مالك بن أنس عن قول الله تعالى \} الرَّمَنُ عَلَّى الْعَشِ استوى \{ُ كيف استوى؟ قال : الكيف بجهول والاستواء غير معقول والإيمان واجب فالسؤال عنه بلدعة.

"Dari Muhammad ibn Syuja' alBalkhiy ia mengatakan: Malik ibn Anas ditanya tentang firman Allah (Tuhan yang Maha Pemurah. yang bersemayam di 'Arsy), bagaimanakan caranya Allah bersemayam? Lalu Malik ibn Anas menjawab: bagaimana caranya Allah bersemayam di Arasy tidaklah diketahui, bersemayam itu sendiri tidaklah bisa dilogikakan, mengimaninya adalah wajib dan mempertanyakannya adalah bid'ah".

Pada umumnya pemahaman ini didasarkan pada jumhur ahlu al-sunnah dari kelompok salaf, namun demikian takwil terhadap ayat ini tetap saja mengalami perkembangan dan perbedaan pendapat, di antaranya adalah; Pertama, Muqatil dan alKalbiy meriwayatkan dari Ibn Abbas bahwa yang dimakasud dengan استواء adalah استقر (menetap). Namun tetap saja takwil ini membutuhkan penakwilan yang baru; Kedua, استواء dari maksud adalah استولى (menguasai). Namun

${ }^{4}$ Al- a'labiy, al-Kasysyaf wa al-Bayan, (ttp:tp, t.th), juz V, h. 369; Lihat juga Jalal alDin al-Suyutiy, al-Itqan fiy 'Ulum al-Qur'an, (Kairo: Dar al-Ghad al-Jadid,2006), juz III, h. 12 pendapat ini dibantah dengan dua alasan, yaitu bahwa Allah SWT adalah penguasa langit, bumi, surga, neraka dan seluruh isinya, lalu apa faedahnya takhshish (pengkhususan) dalam ayat ini dengan arasy. Kemudian kata استيلاء biasanya digunakan untuk penaklukan atau penguasaan terhadap apa yang sudah ditaklukkan, sedangkan Allah SWT Mahasuci dari hal seperti ini; Ketiga, sesungguhnya maksud dari استواء itu adalah صendaki). Maksudnya Allah naik ke arasy untuk menciptakan langit; Keempat, sesungguhnya ungkapan (الرحمن على) memaksudkan (Allah adalah yang tertinggi dari yang tinggi). ${ }^{5}$

Al-Zamakhsyariy dalam alKasysyaf memberikan takwil lain terhadap ayat ini. Menurutnya" عَلَى الْْرَش استوَى

استواء على العرش وهو سرير الملك مما يردف الملك، جعلوه كناية عن الملك فقالوا: استوى فلان على العرش، يريدون: ملك وإن لم يقعد على السرير البتة، وقالوه-أيضا- لشهرته في ذلك المعنى ومساواته ملك في مؤداه وإن كان أشرح وأبسط وأدل على صورة الأمر

Menurut al-Zamakhsyariy adalah pembaringannya sang penguasa. Ini

5 Jalauddin Abdurrahman al-Suyuthiy, Ibid., h. 13.

${ }^{6}$ Abu al-Qasim Jar Allah Mahmud ibn Umar al-Zamakhsyariy selanjutnya disingkat dengan al-Zamakhsyariy, al-Kasysyaf 'an Haqa'iq Ghowamidhi al-Tanzil wa 'Uyun alAqawil fiy Wujuh al-Ta'wil, (Riyadh: Maktabah al-'Ubaikan, 1998), Cet. ke-1, Juz IV, h. 67 
adalah berupa kinayah/ kiasan (majaz) terhadap kekuasaan yang serba mutlak. Seperti sering ada ungkapan استوى فلان على العرش seseorangan (seseorang bersemayam di arasy/ singgasananya). Maksud ungkapan ini adalah bahwa dia memiliki kuasa atas singgasananya walaupun ia tidak sedang duduk di sana. Ini juga mengindikasikan bahwa yang masyhur atau yang mudah dipahami manusia adalah ketika ada pengumpamaan (majaz) dengan arasy walau عَلَى الْعَشْ استِوى dalam ayat itu lebih luas dan lebih tepat.

Al-Zamakhsyariy juga mentakwilkan ayat yang berkaitan dengan ketauhidan (sifat-sifat Allah)

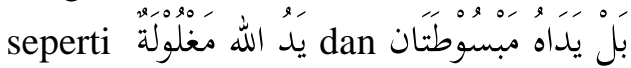
pada (Q.S. Al-Maidah/5: 64)

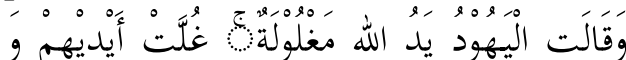

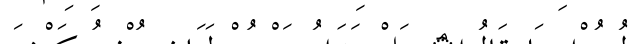

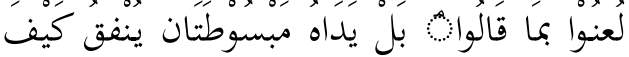

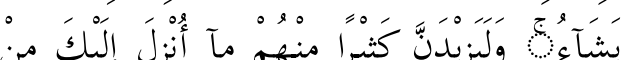

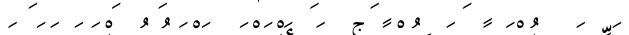

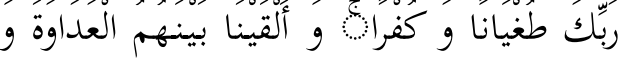

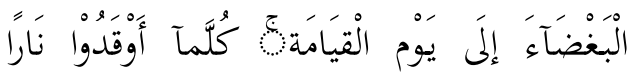

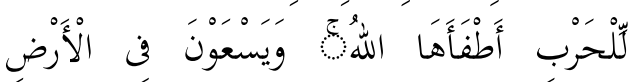

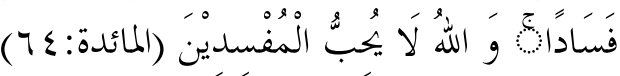
يَ الله adalah: majaz dari bakhil dan dermawan, yang berpendapat tentang itu tidak bermaksud dengan penetapan tangan dan tidak juga terbelenggu dan tidak juga terbuka, menurut dia tidak ada perbedaan antara perkataan ini dengan apa yang menjadi majaz darinya dikarenakan kedua-duanya perkataanperkataan yang menggantikan hakikat yang sama, sehingga dia memakainya dalam kepemilikan yang tidak diberi pemberian sama sekali dan tidak ada yang melarangnya kecuali dengan isyaratnya dengan tidak menggunakan tangan yang terbuka dan tangan yang tertutup, walaupun diberikan oleh tangan yang buntung kepada pundak dengan pemberian yang sangat melimpah kemudian berkata: tidak terbuka tangannya dengan pemberian, dikarenakan terbukanya tangan dan tertutupnya adalah dua perumpamaan yang terjadi saling bergantian bagi orang yang bakhil dan dermawan, dan kedua-duanya telah dipergunakan ketika tangan sedang sakit. ${ }^{7}$

Menurut Ahmad Abdul Maujud: Inti dari penggunaan majaz ini adalah pengibaratan al-haqiqah alma'nawiyah dengan gambaran indera yang lazim, dan tidak ada sesuatu yang tetap atau kekal dalam pikiran dari gambaran panca indera; ketika dermawan dan bakhil dua istilah yang tidak diketahui dengan indera dan diharuskan keduanya pengibaratan yang diketahui oleh indera dan itu adalah tangan terbuka untuk orang yang dermawan dan tangan yang tertutup bagi orang yang bakhil, keharusan pengibaratan terhadap keduanya untuk menetapkan dan memindahkan dari al-ma'nawiyat kepada panca indera. ${ }^{8}$

Dari contoh-contoh ayat yang ditakwilkan oleh al-Zamakhsyariy, bahwasanya ayat-ayat yang ditakwilkan al-Zamakhsyariy adalah

\footnotetext{
${ }^{7}$ Al-Zamakhsyariy, op.cit., Juz II, h. 265

${ }^{8}$ Ibid.,
} 
ayat-ayat mutasyabih yang mana alZamaksyariy mentakwilkannya dengan makna kinayah atau kiasan, dan pentakwilan ini juga lebih cenderung kepada penguatan pokok-pokok ide teologi dari mazhab Mu'tazilah yaitu al-Ushul al-Khamsah.

Itulah beberapa contoh takwil yang diungkapkan oleh beberapa ulama, namun selalu saja perkembangan terhadap takwil tetap berkembang sesuai dengan perkembangan ruang dan waktu. Dengan kata lain takwil, tafsir dan majaz akan selalu hidup dalam masyarakat pencinta al-Qur'an. Ini menandakan bahwa al-Qur'an memiliki begitu banyak aspek yang dikandung, sehingga satu ayat dapat dilihat dari berbagai aspek. Dalam hal ini Jalal al-Din al-Suyuthiy memberikan komentar dengan mengambil sebuah riwayat yang ia kutip dari Muqatil, yaitu:

$$
\text { وجوها كثيرا }
$$

"Seseorang belum bisa dikatakan betul-betul paham dengan al-Qur'an sebelum ia dapat menangkap makna dan kandungan al-Qur'an dari berbagai aspek terkait”.

Maka dari itu kajian dan penelitian terhadap tafsir, takwil tidak boleh terhenti. Ini bertujuan untuk melakukan pembaharuan pemikiran sebagai reaktualisasi Islam yang alQur'an menjadi sumber utamanya. Agar al-Qur'an itu bisa direaktualisasikan, maka di antara langkah yang dibutuhkan, antara lain, adalah;

\footnotetext{
${ }^{9}$ Jalal al-Din al-Suyutiy, op.cit., juz II,
}

1. Perlunya dikembangkan penafsiran sosial struktural dari pada penafsiran individual ketika memahami ketentuan-ketentual tertentu di dalam al-Qur'an.

2. Mengubah cara berpikir subjektif ke cara berpikir objektif ketika memahami dan menafsirkan alQur'an.

3. Mengubah Islam yang normatif menjadi teoritis. Ini bertujuan agar penafsiran itu tidak hanya normatif belaka, akan tetapi diharapkan bisa menjadi kerangka-kerangka teori ilmu.

4. Mengubah pemahaman yang ahistoris menjadi historis. Seperti kisah-kisah yang ada di dalam alQur'an, sehingga penafsiran itu menjadi hidup dan berdasarkan fakta.

5. Merumuskan formulasi-formulasi wahyu yang bersifat general menjadi formalasi-formulasi yang spesifik dan empiris. ${ }^{10}$

Pada periode awal, orang menganggap bahwa tidak hanya bahasa Arab saja yang menjadi alat dan acuan dalam menafsirkan al-Qur'an, namun juga harus memahami idiom-idiom Bahasa Arab pada zaman Nabi. Dari sini berkembanglah ilmu gramatika Bahasa Arab, ilmu-ilmu kesusasteraan dan buku-buku mu'jam. Kemudian setelah itu berkembang lagi ilmu tentang latar belakang turunnya ayat alQur'an yang disebut dengan ilmu asbab al-nuzul. Ilmu asbab al-nuzul menjadi alat yang penting dalam menerapkan makna yang tepat dalam al-Qur'an. Selanjutnya yang terakhir adalah tradisi historis dan sosiologis yang berisi laporan-laporan tentang

10 Kuntowijoyo, Paradigma Islam, Interpretasi untuk Aksi, (Bandung: Mizan, 1999), Cet. ke-9, h. 283 - 285 
bagaimana kehidupan orang-orang dan masyarakat yang berada di sekitar Nabi. ${ }^{11}$ Mungkin yang terakhir ini menjadi salah satu panduan yang digunakan oleh al-Zamakhsyariy ketika memberikan takwil pada ayat sebelumnya, di mana ia mengungkapkan bahwa adanya kinayah/ kiasan (majaz) yang diungkapkan di dalam al-Qur' an adalah untuk memberikan petunjuk dan hidayah bagi umatnya. Kemudian ini juga menjadi salah satu pondasi untuk perkembangan dan implikasi takwil dalam menafsirkan ayat-ayat alQur'an.

Al-Zamakhsyariy $(467 \mathrm{H}-538 \mathrm{H})$ adalah salah seorang ulama tafsir terkemuka dari kelompok Mu'tazilah dan bermazhab Hanafiyah. Ia menguasai tafsir, hadis, nawhu, bahasa, sastra serta menguasai berbagai ilmu pengetahuan. Sehingganya semua ini memberi corak tersendiri dalam kitab tafsirnya, yang penafsirannya banyak mengungkap masalah kebahasaan dan takwil. ${ }^{12}$

Salah satu keistimewaan yang dimiliki oleh kelompok Mu'tazilah terkait tafsir adalah majaz. Menurut alJahiz, majaz memiliki jenis dan unsurunsur yang berbeda, seperti kinayah, tasybih, isti'arah, hadzf dan sebagainya. Menurutnya peran bahasa terbatas pada fungsinya sebagai alat penjelasan (ibanah). Fungsi tersebut merupakan suatu keniscayaan dalam lingkungan komunitas manusia, khususnya untuk saling tukar informasi dan pengetahuan. Selama hal itu

11 Fazlur Rahman, Islam, Penerjemah: Ahsin Mohammad, (Bandung: Pustaka Bandung, 2000), Cet. ke-4, h. 48 op.cit., h. 433

12 Muhammad Husein al-Zahabiy, 76 merupakan keniscayaan, maka dengan sendirinya orang-orang akan menggunakan bahasa dengan cara yang mereka yakini dapat berfungsi untuk merealisasikan hal tersebut. Lebih lanjut menurut al-Jahiz bahwa ada dua hal yang harus dipenuhi ketika seseorang mengungkapkan perkataan dalam bentuk majaz; Pertama, ada keterkaitan antara makna yang terambil dan makna yang dituju melalui perkataan tersebut; Kedua, transformasi makna harus melalui proses kesepakatan kolektif, bukan semata-mata didasarkan pada kebebasan individual. ${ }^{13}$

Sudah tentu semua ini menjadi acuan bagi al-Zamaksyariy dalam menyusun kitab tafsirnya, sehingga corak majaz dan takwil sangat rentan dalam kitab tafsirnya. Hal ini terlihat dalam ungkapan Muhammad Ilyan dalam muqaddimah kitab tafsir alKasysyaf;

فمن المعلوم أن تفسير العلامة الزخشرى قد بلغ الغاية في البيان، والكشف عن اسرار القرآن، لكن قد حجب الراغبين فيه عن مدارسته وحرمهم من كثرة ممارساته مااشتمل عليه من تأويل الآيات الواردة في المسائل التوحيدية

"Sudah sangat dimaklumi bahwa tafsir seorang tokoh yang bernama alZamakhsyariy telah mencapai penjelasan yang sempurna, ia berhasil mengungkap rahasia-rahasia alQur'an, hanya saja sebahagian para

13 Nashr Hamid Abu Zaid, al-Ittijahat al- 'Aqliy fiy al-Tafsir, Dirasah fiy Qadhiyat alMajaz fiy al-Qur'an 'Inda al-Mu'tazilah, (Beirut: Al-Markaz al- aqofiy al-Arabiy, 1996), Cet. ke-3, h. 111

${ }^{14}$ Al-Zamakhsyariy, op.cit., juz I, h. 3 
pemerhati sedikit terhalangi (risih) ketika hendak mempelajari kitab tafsirnya, di mana mereka mengecam banyaknya terjadi praktek pena'wilan ayat-ayat yang berhubungan dengan masalah tauhid".

Berbagai indikasi di atas menarik untuk diungkapkan lebih lanjut, artinya bagaimana implementasi takwil dalam tafsir al-Kasysyaf oleh alZamakhsyariy, sejauh mana pemahaman ajaran Mu'tazilah mempengaruhi pentakwilan alZamakhsyariy?. Hal ini dan persoalanpersoalan lain yang terkait dengannya akan dipaparkan dalam tulisan ini.

\section{Implementasi Takwil Dalam Tafsir Al-Kasysyaf Oleh Al-Zamakhsyariy}

\section{Hasil Pentakwilan al- Zamakhsyariy}

a. Al-Zamakhsyariy mentakwilkan mutasyabih.

ayat-ayat

Dalam mentakwilkan ayat-ayat mutasyabih al-Zamakhsyariy mengelompokkan menjadi dua, adalah:

1) Ayat-ayat mutasyabih yang bermakna kiasan

Seperti Q.S. Thaha/20: 5

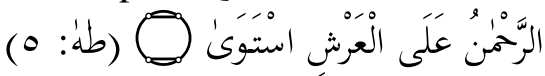

Menurut al-Zamakhsyariy dalam mentakwilkan " استواء على " "العرش adalah pembaringannya sang penguasa. Ini adalah berupa kinayah/ kiasan (majaz) terhadap kekuasaan yang serba mutlak. Seperti sering ada ungkapan "استوى فلان على العرش" seseorangan (seseorang bersemayam di arasy/ singgasananya). Maksud ungkapan ini adalah bahwa dia memiliki kuasa atas singgasananya walaupun ia tidak sedang duduk di sana. Ini juga mengindikasikan bahwa yang masyhur atau yang mudah dipahami manusia adalah ketika ada pengumpamaan (majaz) dengan arasy walau sesungguhnya makna "استواء على العرش“ dalam ayat itu lebih luas dan lebih tepat. ${ }^{15}$

2) Ayat-ayat mutasyabih yang berkaitan dengan al-ushul alkhamsah, khususnya masalah alTauhid.

Dalam ajaran Mu'tazilah bahwa Tuhan itu Maha Melihat, mendengar dan sebagainya, itu bukan sifat melainkan zat-Nya. Menurut Mu'tazilah sifat Tuhan itu adalah zat Tuhan itu sendiri, seperti Tuhan mengetahui dengan ilmu dan ilmu itu adalah Tuhan, berkuasa dengan kekuasan dan kekuasaan itu adalah Tuhan. Dengan demikian penguasaan, pengetahuan dan kekuasaan Tuhan adalah Tuhan, zat dan esensi Tuhan, bukan sifat yang menempel pada zatnya, untuk memahami paham ini mereka menganut paham Qadariah. ${ }^{16}$ Seperti Q.S. Al-Fath/48: 10

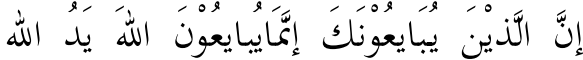
فَوقَ

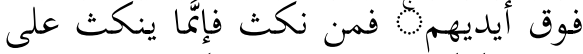

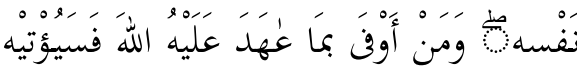

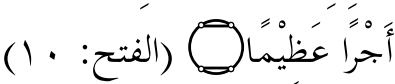

Al-Zamakhsyariy menjelaskan tentang potongan ayat yang

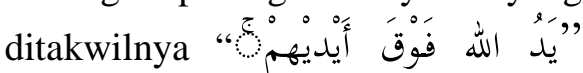
adalah tangan Rasullullah yang

${ }^{15} \mathrm{Ibid}$., Juz IV, h. 67

${ }^{16}$ Abdul Rozak, \& Rosihon Anwar, Ilmu Kalam, (Bandung: Pustaka Setia, 2013), h. 100. 
terletak diatas tangan orang-orang yang sedang melakukan bai'at (bai'at al-ridhwan). Di dasari dengan akidah, bahwa Allah tidak bertubuh dan tidak pula beranggota badan. Jadi, ayat tersebut diatas memberikan pengertian bahwa mengikat perjanjian dengan Rasulullah sama artinya dengan mengikat perjanjian dengan Allah, seperti firman Allah dalam Q.S. AlNisa'/4: 80

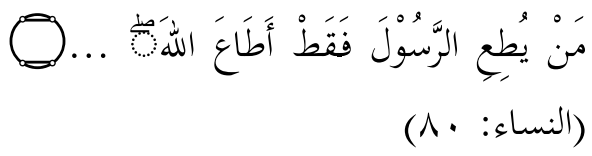

b. Al-Zamakhsyariy mentakwil lafal-lafal atau ayat-ayat alQur'an yang tidak sesuai dengan mazhabnya (al-ushul alkhamsah)

Seperti contoh Q.S. AlQiyamah: 22-23

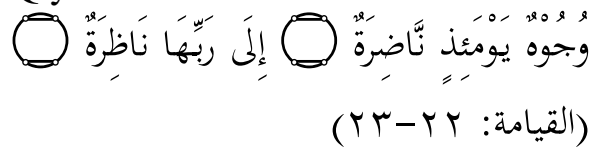
Al-Zamakhsyariy di dalam kitabnya mentakwilkan ayat ini berbeda dengan pemahaman mazhabnya dan sependapat dengan para mufassir pada umumnya. AlThabariy dalam kitabnya Jami' alBayan memaparkan bahwa para mufassir berbeda dalam menafsirkan kata nazhirah. Sebagian berpendapat bahwa maknanya adalah melihat Allah. Sedangkan sebagian yang lain berpendapat bahwa makna lafal nazhirah adalah

\footnotetext{
${ }^{17}$ Ibid., Juz V, h. 537-538
}

menunggu pahala dari Allah. ${ }^{18}$ Pendapat ini mengindikasikan bahwa al-Thabariy dalam menafsirkan kata nazhirah tidak terpaku pada satu pendapat. Ibnu $\mathrm{Ka}$ ir dalam kitabnya mengatakan bahwa makna lafal nazhirah dalam ayat tersebut adalah melihat Allah dengan mata telanjang yang diperkuat oleh hadis mutawatir yang diriwayatkan oleh Imam Bukhari. ${ }^{19}$

Al-Zamakhsyariy menafsirkan lafal nazhirah dengan melihat Allah, ${ }^{20}$ tidak memalingkan makna zahir kata tersebut kepada makna altawaqqu' wa al-raja' (berharap) sebagaimana yang dilakukan oleh pemahaman mazhabnya. Sebenarnya, ayat ini berbicara tentang kemampuan manusia untuk melihat Allah pada hari kiamat. Namun, al-Zamakhsyariy dalam menafsirkan ayat ini tidak terpengaruh oleh salah satu prinsip mazhab Mu'tazilah yang dianutnya, yaitu prinsip al-tauhid. Dalam prinsip al-tauhid kaum Mu'tazilah menolak adanya tajsim (penyerupaan terhadap sifat makhluk) bahwa melihat Tuhan adalah suatu hal yang mustahil. Sehingga jika lafal nazhirah dimaknai sebagai "melihat", tentu penafsiran semacam ini akan menyalahi dan merusak paham altauhid yang ia yakini dan juga bertentangan dengan firman Allah

18 Al-Thabariy, Jami' al-Bayan a'n Ta'wil al-Qur'an, ( Beirut: Muassah al-Risalah, 1994), Cet. ke-1, jilid 7, h. 414

19 Ibnu Ka ir, Tafsir al-Qur'an alAzhim,(tp., Muassasah Qurthubah, 2000), Cet. ke-1, Jilid 14, h. 198.

${ }^{20}$ Al-Zamakhsyari, op.cit., Juz VI, h. 
dalam Q.S. Al-An'am/6: 103 “ لا

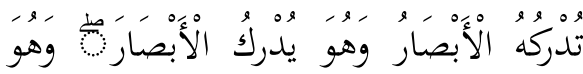

"اللَّيْف ؛ Karena itulah, kata

nazhirah yang makna zahirnya melihat, tidak ia palingkan maknanya kepada makna lain, yaitu al-raja' (berharap). Dengan penafsiran seperti ini, ia telah berusaha netral dalam menafsirkan ayat al-Qur'an tanpa menyalahi prinsip-prinsip mentafsirkan atau mentakwilkan ayat-ayat al-Qur'an, meskipun masih banyak didapatu penatalwilannya berlandaskan pemahaman mazhab Mutazilah.

\section{c. Al-Zamakhsyariy} mentakwilkan ayat-ayat bukan mutasyabih (muhkam).

Ayat-ayat yang ditakwil oleh alZamakhsyariy yang tidak termasuk dengan ayat-ayat bukan mutasyabih (muhkam) adalah ayat-ayat yang berkaitan dengan ajaran Mu'tazilah (al-ushul al-khamsah) kecuali masalah al-tauhid dan al-manzilah baina al-manzilataini beserta contoh ayat-ayat yang ditakwil yang berkaitan dengan ajarannya.

\section{Al-'Adl (Keadilan)}

Keadilan menurut ajaran Mu'tazilah adalah Tuhan Maha Adil. Adil adalah suatu atribut yang paling jelas untuk menunjukkan kesempurnaan, karena Tuhan Maha Sempurna sudah pasti adil. Aliran Mu'tazilah ini ingin menempatkan Tuhan benar-benar adil menurut sudut pandang manusia. Tuhan dipandang adil apabila bertindak hanya yang baik dan terbaik dan bukan yang tidak baik. Begitu pula
Tuhan itu adil apabila tidak melanggar janji-Nya. ${ }^{21}$

Sebagaimana firman Allah dalam Q.S. Al-Baqarah/2: 272

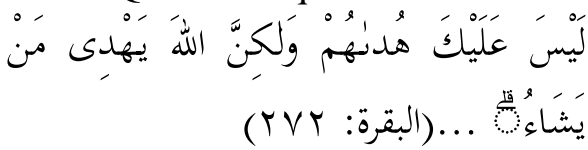

Al-Zamakhsyariy di dalam kitabnya mentakwilkan lafal " وَككنَّ الله

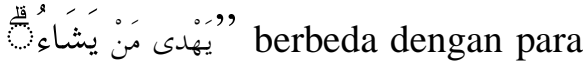
mufassir pada umunya. Dalam tafsir

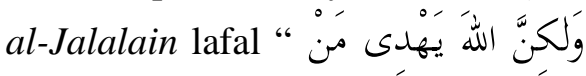
"يشَاءُ" bermakna hidayah untuk masuk Islam, ${ }^{22}$ dan menurut al-

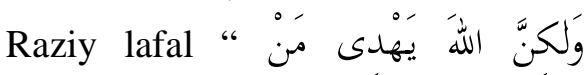
"يشَاءُ" tentang akan tercapainya hidayah dengan cara berusaha dan ini akan terwujud dengan takdir Allah. ${ }^{23}$

Sedangkan al-Zamakhsyari dalam kitabnya mentakwilkan lafal

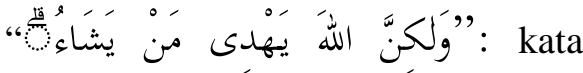
"يَهُندى" ditakwilkan oleh al" اللطف " atau anugerah, jadi Allah hanya memberikan anugerah kepada orang-orang yang mengerti bahwa anugerah itu bermanfaat bagi dirinya. Kemudian dengan anugerah tersebut, manusia akan meninggalkan perbuatan-perbuatan

\footnotetext{
${ }^{21}$ Abdul Rozak, \& Rosihon Anwar, Ilmu Kalam, op.cit., h. 102

22 Jalalain, Tafsiir al-Jalalain, (ttp., Dar Ibnu $\mathrm{Ka}$ ir, tt), h. 46

23 Muhammad al-Raziy Fakhruddin, Mafatih al-Ghoib, (Beirut: Dar al-Fikr, 1981), Cet. ke-1, h. 83.
} 
yang terlarang. ${ }^{24}$ Terlihat jelas dari pentakwilan yang dilakukan oleh alZamakhsyariy dipengaruhi oleh ajaran Mu'tazilah tentang keadilan, yang mana Allah Maha Adil dan sangat tidak pantas jika Allah menyiksa seseorang akibat dosa yang dilakukannya secara tidak sengaja. Sebab, yang demikian termasuk zhalim (aniaya). Berdasarkan prinsip keadilan ini, Mu'tazilah meyakini bahwa Allah tidak menciptakan perbuatan manusia, tetapi manusia itu sendiri yang menciptakan perbuatannya.

2. Al-Wa'd wa al-Wa'id (Janji dan ancaman)

Ajaran yang ketiga ini sangatlah erat hubungannya dengan ajaran kedua di atas. $A l-W a ' d$ wa alWa'id berarti janji dan ancaman. Menurut pemahaman Mu'tazilah Tuhan itu Maha Adil, Maha Bijaksana dan tidak akan melanggar janjinya. Kemudian aliran ini juga mengatakan bahwa Tuhan-Nya hanyalah melaksanakan janji-Nya. Menurut mereka mau tidak mau mesti terjadi sesuai dengan apa yang telah dijanjikan, perbuatan Tuhan terikat dan dibatasi oleh janji-Nya surga dan neraka. ${ }^{25}$ Berikut ini contoh ayat yang ditakwil tentang al-Wa'd wa al-Wa'id: Q.S. AlAn'am/6: 158

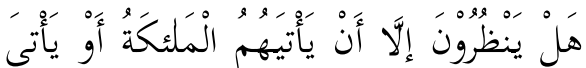

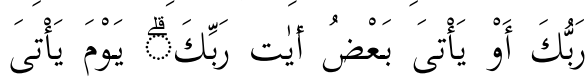

24 Al-Zamakhsyariy, op.cit., Juz I, h. 501-502

${ }^{25}$ Abdul Rozak, \& Rosihon Anwar, Ilmu Kalam, op.cit., h. 105

80

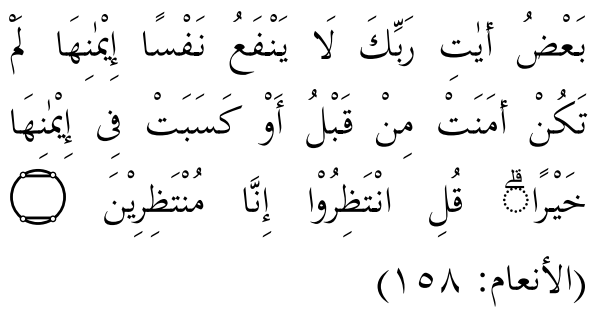

Al-Zamakhsyariy di dalam kitabnya mentakwilkan lafal " قُل

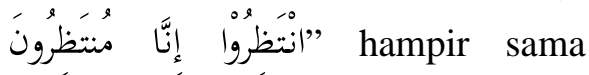
dengan mufassir lainnya, menurut Ibnu Kasiir dalam kitabnya makna

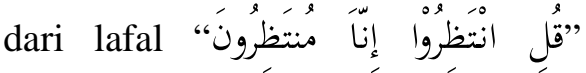
adalah ancaman untuk orang-orang kafir dan ancaman yang keras bagi orang-orang yang menunda-nunda dalam menyempurnakan imannya dan menunda-nunda untuk bertaubat hingga datang waktu yang tidak ada gunanya menyempurnakan iman dan taubat, dan sesungguhnya ini adalah hukuman ketika hari kiamat. ${ }^{26}$ Dan menurut al-Qurthubiy makna

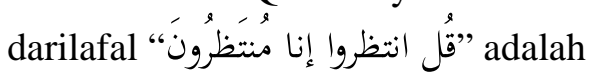
azab untuk kalian. $^{27}$ Sedangkan menurut al-Zamakhsyari makna dari

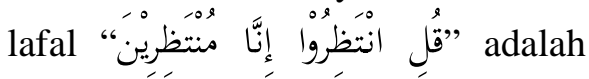
ancaman bagi orang-orang yang tidak menyegerakan dalam menyempurnakan imannya dan juga untuk orang-orang yang tidak menyegerakan bertaubat. ${ }^{28}$

26 Ibnu Kasiir, Tafsir al-Qur'an alA'zhim, (Ttp: Muassasah Qurthubah, 2000), Cet. ke-1, Juz V, h. 237

27 Al-Qurthubiy, al-Jami' li Ahkam alQur'an, (Beirut: Muassasah al-Risalah, 2006), Cet. ke-1, Juz IX, h. 133

${ }^{28}$ Al-Zamakhsyariy, op.cit., Juz II, h. $415-416$ 
3. Al-Amr bi al-Ma'ruf wa al-Nahyi 'an al-Munkar

Al-Amr bi al-Ma'ruf wa alNahyi 'an al-Munkar adalah menyuruh kita kepada kebajikan dan melarang kepada kemungkaran, ajaran ini menekankan keberpihakan pada kebenaran dan kebaikan. Ini merupakan konsekuensi logis dari keimanan seseorang. Pengakuan keimanan ini harus dibuktikan dengan perbuatan baik. $^{29}$ Adapun contoh ayat yang ditakwil tentang al-Amr bi al-Ma'ruf wa al-Nahyi 'an al-Munkar adalah (Q.S. Ali 'Imran/3: 104):

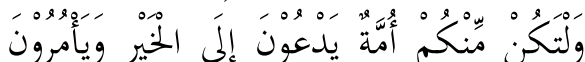

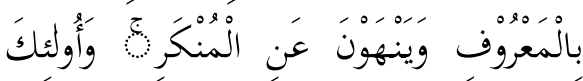

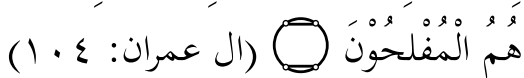

Al-Zamakhsyariy berpendapat tentang ayat ini, bahwasanya perintah menyeru berbuat kebaikan yang tertuang dalam ayat diatas adalah fardu kifayah, dikarenakan

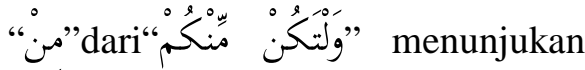

arti sebagian. Pelaksanaan seruan harus terdiri dari orang-orang yang mengerti tentang kebaikan dan kemungkaran, dan ilmu bagaimana menyusun sesuatu untuk menegakkannya dan ilmu bagaimana mengendalikannya atau memenejnya, kalau seandainya orang bodoh, mungkin akan melarang yang ma'ruf dan menyuruh kepada kemungkaran, dan mungkin juga mengetahui aturan mazhabnya dan tidak mengetahui aturan mazhab temannya.

${ }^{29}$ Abu Hasan Ismail al-Asy'ari, Prinsipprinsip Dasar Aliran Theologi Islam, (Bandung: Pustaka Setia,1998), h. 29
Ada juga yang mengatakan “من" untuk menjelaskan, maksudnya adalah: jadilah umat yang menyeru, sebagaimana firman Allah dalam Qُنتم خَير أُمَّة (

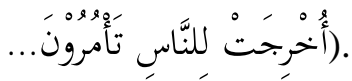

Adapun menyeru kepada kebaikan, menurut al-Zamakhsyariy adalah mengikuti yang memberi perintah, jika wajib maka wajib hukumnya, dan jika sunnah maka sunnah hukumnya, sedangkan mencegah perbuatan mungkar, adalah wajib secara keseluruhan, karena meninggalkan seluruh perbuatan mungkar itu wajib dikarenakan perbuatan mungkar itu adalah sifat yang buruk.

Al-Zamakhsyariy juga menjelaskan metode wajib "ada dua pendapat ulama, pertama: Abi Ali dengan pendengaran dan akal, sedangkan yang kedua Abu Hasyim dengan pendengaran saja. Dan juga menjelaskan syarat-syarat nahyi "seseorang yang melarang harus mengetahui bahwa apa yang dilarangnya adalah keburukan, jika ia tidak mengetahuinya, orang tidak akan percaya, dan menjadikannya memerangi kebaikan, jika seandainya apa yang dilarangnya tidak terjadi, dikarenakan kejadian tidak memperbaiki apa yang dilarangnya, dan sesungguhnya hanya memperbaiki keburukan baginya dan larangan dari contohcontohnya, dan apabila tidak menang atas prasangkanya, bahwasanya orang yang melaran menambah kemungkarankemungkaarannya, dan sesungguhnya pelarangannya tidak 
mendatangkan faedah karena itu adalah sia-sia".

Al-Zamakhsyariy juga menjelaskan syarat-syarat wajib "prasangkanya harus menang, bahwasanya jika ia mengerjakan pekerjaan yang mungkar, ia akan mendapatkan kesusahan yang besar". Dan juga menjelaskan cara mengurus kemungkaran "dimulai dengan yang mudah, jika tidak bermanfaat atau berhasil, maka beralih kepada yang sulit, karena tujuannya adalah menghentikan kemungkaran. Sebagaimana firman Allah (فأصلحوا بينهما), kemudian:

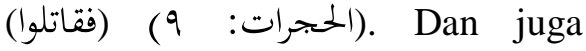
menjelaskan siapa saja yang mengurus kemungkaran "setiap muslim". Dan juga menjelaskan siapa saja yang mendapatkan perintah dan mendapat larangan "setiap yang telah ditaklif". Dan juga menjelaskan tentang apakah orang yang melakukan kemungkaran wajib melarang terhadap kemungkaran yang ia lakukan "wajib baginya, karena meninggalkan apa yang dilakukannya dan kemungkarannya adalah kewajiban bagi mereka, maka dengan meninggalkan salah satu dari kewajibannya tidak akan menjatuhkan atau menghilangkan kewajiban yang lain baginya". ${ }^{30}$

\section{KESIMPULAN}

Dari uraian-uraian pada bab-bab di atas dapat di simpulkan bahwa: Hasil penta'wilan al-Zamakhsyariy; Mentakwil ayat-ayat mutasyabih,

${ }^{30}$ Al-Zamakhsyariy, op.cit., Juz I, h. 604-606

82 mentakwil ayat-ayat yang tidak sesuai dengan pemahaman mazhabnya, Mentakwil ayat-ayat bukan mutasyabih (muhkam)

\section{DAFTAR PUSTAKA}

Arikunto, Suharsimi, 2006, Prosedur Penelitian Suatu Pendekatan Praktik, Jakarta: Rineka Cipta.

Al-Asy'ari, Abu Hasan Ismail,1998, Prinsip-prinsip Dasar Aliran Theologi Islam, Bandung: Pustaka Setia.

Azra, Azyumardi (ed), 1999, Sejarah dan Ulum al-Qur'an, Jakarta: Pustaka Firdaus.

Bungin, Burhan, 2003, Analisis Data Kualitatif, Jakarta: Grafindo Raja Persada.

Fakhruddin, Muhammad al-Raziy, 1981, Mafatih al-Ghoib, Beirut: Dar al-Fikr.

Hidayat, Komaruddin, 1998, Tragedi Raja Midas, Moralitas Agama dan Krisis Modernisme, Jakarta: Paramadina.

Jalalain, tth, Tafsiir al-Jalalain, ttp., Dar Ibnu Ka ir.

Ka ir, Ibnu, 2000, Tafsir al-Qur'an alAzhim,tp., Muassasah Qurthubah.

Kuntowijoyo, 1999, Paradigma Islam, Interpretasi untuk Aksi, Bandung: Mizan.

Manzur, ibn, t.th, Lisan al-Arab, Beirut: Dar Shadir.

Nasir, Muhammad, 1998, metodologi Penelitian Jakarta: Ghalia Indonesia. 
Nasution, Harun, 1996, Islam Rasional, Gagasan dan Pemikiran Prof. Dr. Harun Nasution, Bandung: Mizan Wacana Ilmu.

Qaththan, Manna' Khalil, 2000, Mabahi fiy 'Ulum al-Qur'an, Kairo: Maktabah Wahbah.

Al-Qurthubiy, 2006, al-Jami' li Ahkam al-Qur'an, Beirut: Muassasah alRisalah.

Rahman, Fazlur, 2000, Islam, Penerjemah: Ahsin Mohammad, Bandung: Pustaka Bandung.

Rozak, Abdul, \& Rosihon Anwar, 2013, Ilmu Kalam, Bandung: Pustaka Setia.

Al- a'labiy, t.th, al-Kasysyaf wa alBayan, ttp:tp.

Shihab, Muhammad Quraish, 1997, Membumikan al-Qur'an, Fungsi dan Peran Wahyu dalam Kehidupan Masyarakat, Bandung: Mizan Wacana Ilmu.

Shihab, Muhammad Quraish, 2000, Tafsir al-Mishbah, Pesan, Kesan dan Keserasian al-Qur'an, Jakarta: Lentera Hati.
Sugiyono, 2013, Metode Penelitian Kombinasi, Bandung: Alfabeta.

Al-Suyutiy, Jalal al-Din, 2006, al-Itqan fiy 'Ulum al-Qur'an, Kairo: Dar al-Ghad al-Jadid.

Al-Thabariy, 1994, Jami' al-Bayan a'n Ta'wil al-Qur'an, Beirut: Muassah al-Risalah.

Al-Zahabiy, Muhammad Husain, 2000, al-Tafsir wa al-Mufassirun, Kairo: Maktabah Wahbah.

Zaid, Nashr Hamid Abu, 1996, alIttijahat al-'Aqliy fiy al-Tafsir, Dirasah fiy Qadhiyat al-Majaz fiy al-Qur'an 'Inda alMu'tazilah, Beirut: Al-Markaz al- aqofiy al-Arabiy.

Al-Zamakhsyariy, 1998, al-Kasysyaf 'an Haqa'iq Ghowamidhi alTanzil wa 'Uyun al-Aqawil fiy Wujuh al-Ta'wil, Riyadh: Maktabah al-'Ubaikan.

Al-Zuhailiy, Wahbah, 1998, Ushul alFiqh al-Islamiy, Beirut: Dar alFikr. 